\title{
Effect of winter conditions on wild ungulates mortality in the Owl Mountains (Poland)
}

\author{
Marcin Warchałowski ${ }^{1} \bowtie$, Piotr Nowakowski ${ }^{2}$,Andrzej Dancewicz ${ }^{3}$ \\ ${ }^{1}$ University of Zielona Góra, Faculty of Biological Sciences, Departament of Zoology, Prof. Z.Szafrana 1, \\ 65-516 Zielona Góra, Poland, e-mail: marcin.warchalowski@dziewiecsil.org \\ ${ }^{2}$ Wrocław University of Environmental and Life Sciences, The Faculty of Biology and Animal Science, \\ Institute of Animal Breeding, Chełmońskiego 38C, 51-630 Wrocław, Poland \\ ${ }^{3}$ Institute of Meteorology and Water Management, Parkowa 30, 51-616 Wrocław, Poland
}

\section{Abstract}

Relations between climatic factors during the winter season (n days with frost $<0^{\circ} \mathrm{C}$ and $-10^{\circ} \mathrm{C}$; $\mathrm{n}$ days with snow cover: $>1 \mathrm{~cm},>10 \mathrm{~cm}$ and $>30 \mathrm{~cm}$; maximum snow cover during season [cm]) and mortality in free-living ungulates (red deer Cervus elaphus Linnaeus, 1758, roe deer Capreolus capreolus Linnaeus, 1758 and mouflon Ovis aries musimon Linnaeus, 1758) in the Owl Mountains (Lower Silesia - Poland) in years 1998-2010 were investigated. Significant effects of all analysed climatic factors on ungulates mortality were documented. Correlations (Pearson) between such weather factors as the depth of snow cover and number of days with frost and recorded mortality in total animal populations analysed ranged from $r=0.33$ to $r=0.77$. The least adapted to local weather conditions was mouflon introduced to this area ca. 100 years ago from more southern parts of Europe. Roe deer species seems to be environmentally plastic, and are doing quite well in severe winters. Tolerance of red deer to the snow cover is much lower at low temperatures due to the fact that this species, during the period of snow cover, has limited access to the plants covered with snow and difficult access to food base.

\section{KeY WORDS}

mortality, mouflon, red deer, roe deer, snow cover, temperature, ungulate, Owl Mountain

\section{INTRODUCTION}

The sustainable existence of ungulates in the environment depends on terrain morphology and atmospheric features as occurrence of snow cover (Mech et al. 1987; Messier 1995; D`Eon 2004), and exposure to low temperature (Barichello and Carey 1988), presence of predators (Jędrzejewski et al. 1992; Hebblewhite et al. 2002; Kittle et al. 2008), and fodder availability. Infe- rior weather conditions influence body condition, diet quality (Wehausen 1992; Goodson et al. 1991; Goodson 1992), food resources (Perzanowski et al. 1982) and rearing ability of offspring (Burles et al. 1984; Picton 1984; Portier et al. 1998; Kumpula and Colpeart 2003). In moderate climatic conditions in the mountainous regions of Central Europe, winter season is the most critical to animals' survival. As observed by Loison et al. (1999) snowy winters resulted in lower body mass of 
offspring and slowed growth of ungulates populations (Albon et al. 1987).

The paper deals with description of the effects of winter conditions on mortality of wild ungulates in the chosen area of the Owl Mountains - Lower Silesia, Poland.

\section{MATERIAL AND METHOdS}

The area of research was situated in Central Sudety Mountains - Owl Mountains (area of ca. $270 \mathrm{~km}^{2}$ ) ranging $30 \mathrm{~km}$ in south-east direction (Kondracki 2011). The altitude of the range was from 600 to $980 \mathrm{~m}$ above sea level, with the highest peak Great Owl (1015 m). Climate in the study area was typical from the Poland, with 170-210 day vegetation period and annual sum of precipitation ranging from 650 to $1000 \mathrm{~m}$ in the height parts mountain. Bystrzyca is the longest river in the Owl Mountains. The landscape is diversified with single or group hills divided by river valleys. Geographical monograph of this region was described in detail by Furmankiewicz (2006). The dominant tree species in hunting area hunting 333 is beech (Fagus sylvatica). Within the woods, there are glades (clearings) and lower parts are under agriculture use. The analysis was performed based on documentation of counting game animals (hunting area no. 333) near Bielawa in Dzierżoniów County - Lower Silesia. An area of 13,652 ha with the $71.2 \%$ share of forest was populated with red deer (Cervus elaphus), roe deer - forest ecotype (Capreolus capreolus) and mouflon (Ovis aries musimon). There were no natural predators in the environment, except foxes (Vulpes vulpes). Since there was intensive fodder supplementation to animals during the winter season, the only factors limiting the population were humans (controlled shooting) and weather conditions.

Mortality data of game animals from 1998 to 2010 year was obtained from census made by Regional Forest Service in hunting area number 333. Yearly reports dealt with the time span from 01 April to 31 March of the next year. The annual mortality reports (number of lost individuals $-\mathrm{N}$ ) were done on the basis of field records done by workers of Regional Forest Service and the police accident reports. Based on annual mortality reports, mortality rate (the ratio of dead individuals of the specific species in one season relative to the number of size of the thousand individuals of the species). Mortality was analysed by sex and age class.
Meteorological data were obtained from weather stations belonging to IMGW-PIB (Institute of Meteorology and Water Management) located within hunting area or in close proximity: temperature readings were from Szczawno Zdrój (altitude $430 \mathrm{~m}$ ), and snow cover readings were from Rościszów (altitude $535 \mathrm{~m}$ ).

The following indices were used for analyses: number of frosty days (day when maximum daily temp did not exceed $0^{\circ} \mathrm{C}$ ), number of days with heavy frost (day when maximum daily temp was below $-10^{\circ} \mathrm{C}$ ), number of days with snow cover (snow cover $>1.0 \mathrm{~cm}$ ), number of days with snow cover $>10 \mathrm{~cm}$, number of days with snow cover $>30 \mathrm{~cm}$, as well as maximum depth of snow cover during season $(\mathrm{cm})$.

Observed mortality rate in animal populations of roe deer, red deer and mouflon in consecutive years were compared with the meteorological data using Pearson's correlations and calculating linear regressions. Cluster analysis (method agglomerative) was used to describe differences between species mortality due to climatic conditions (statistical package Statistica v. 10.0).

\section{Results}

The used data (Table 1) represent only minor proportion of real mortality that occur in nature. In the present study, less than $3 \%$ of population was related to documented yearly mortality.

Table 1. Recorded mortality of three species of ungulates in years 1998-2010

\begin{tabular}{|l|c|c|c|}
\hline \multicolumn{1}{|c|}{ Item } & $\begin{array}{c}\text { Red } \\
\text { deer }\end{array}$ & $\begin{array}{c}\text { Roe } \\
\text { deer }\end{array}$ & Mouflon \\
\hline $\begin{array}{l}\text { Total mortality during } \\
12 \text { seasons (n) }\end{array}$ & 78 & 130 & 107 \\
\hline $\begin{array}{l}\text { Average recorded losses per } \\
\text { year (n) } \\
\begin{array}{l}\text { Mean } \pm \text { SD } \\
{[\text { min-max }]}\end{array}\end{array}$ & $\begin{array}{c}7 \pm 2 \\
{[2-10]}\end{array}$ & $\begin{array}{c}11 \pm 8 \\
{[1-26]}\end{array}$ & $\begin{array}{c}9 \pm 10 \\
{[1-37]}\end{array}$ \\
\hline $\begin{array}{l}\text { Average annual mortality } \\
\text { rate }\end{array}$ & 18.6 & 34.1 & 16.5 \\
\hline
\end{tabular}

Mortality of wild ungulates from 1998 to 2010 (Figure 1) showed fluctuations between seasons with the peak mortality rate resembling pattern of [n] days with snow cover over $10 \mathrm{~cm}$. 


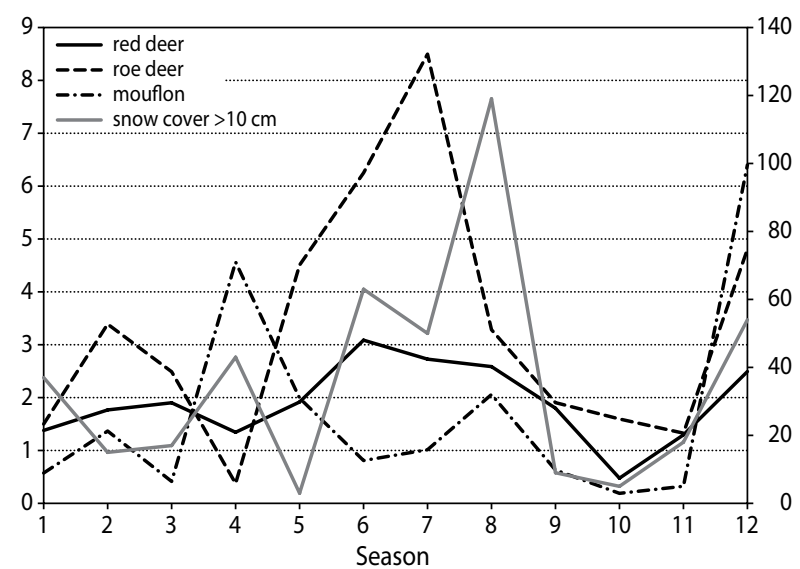

Figure 1. Number of mortality (n) of wild ungulates in season (1998-2010). Axe Y presents - animal mortality (left axe) and $\mathrm{n}$ days with snow cover $>10 \mathrm{~cm}$ (right axe)

Table 2. Correlation coefficients (r) between weather factors (traits, indices) and mortality of red deer, roe deer and mouflon (Bolts $-\mathrm{P} \leq 0.05$ )

\begin{tabular}{|c|c|c|c|c|c|c|c|c|}
\hline \multirow[t]{2}{*}{ Item } & \multirow[t]{2}{*}{ 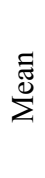 } & \multirow[t]{2}{*}{ के } & \multirow[t]{2}{*}{$\stackrel{\Xi}{\Sigma}$} & \multirow[t]{2}{*}{$\stackrel{\varkappa}{\stackrel{\varkappa}{\Sigma}}$} & $\begin{array}{l}\dot{0} \\
\stackrel{d}{0} \\
\stackrel{0}{0} \\
\tilde{\simeq}\end{array}$ & 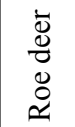 & 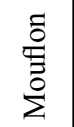 & 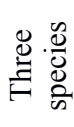 \\
\hline & & & & & \multicolumn{4}{|c|}{ Mortality (r) } \\
\hline $\begin{array}{l}\text { Maximum } \\
\text { height of snow } \\
\text { cover }[\mathrm{cm}]\end{array}$ & 46 & 26 & 12 & 106 & 0.43 & 0.23 & 0.05 & 0.33 \\
\hline $\begin{array}{l}\text { Number of } \\
\text { days witch } \\
\text { snow cover [n] }\end{array}$ & 67 & 26 & 27 & 131 & 0.65 & 0.38 & 0.29 & 0.51 \\
\hline $\begin{array}{l}\text { Number of } \\
\text { days witch } \\
\text { snow cover } \\
>10 \mathrm{~cm}[\mathrm{n}]\end{array}$ & 38 & 31 & 3 & 119 & 0.62 & 0.30 & 0.31 & 0.47 \\
\hline $\begin{array}{l}\text { Number of } \\
\text { days witch } \\
\text { snow cover } \\
>30 \mathrm{~cm}[\mathrm{n}]\end{array}$ & 16 & 20 & 0 & 66 & 0.52 & 0.26 & 0.43 & 0.51 \\
\hline $\begin{array}{l}\text { Number of } \\
\text { frosty days [n] }\end{array}$ & 33 & 14 & 4 & 55 & 0.56 & 0.51 & 0.46 & 0.69 \\
\hline $\begin{array}{l}\text { Number of } \\
\text { heavy frosty } \\
\text { day }[\mathrm{n}]\end{array}$ & 1 & 1 & 0 & 5 & 0.40 & 0.33 & 0.75 & 0.77 \\
\hline
\end{tabular}

All analysed indices of weather conditions were related to losses in wild ungulates in the Owl Mountains (Table 2). Analysis of correlations showed that, for all three species together, the length of presence of snow cover had a significant effect on ungulate mortality $(\mathrm{r}=0.51 ; \mathrm{P} \leq 0.05)$. The number of days with the depth of snow either $>10 \mathrm{~cm}$ or $>30 \mathrm{~cm}$ generally did not affect this relation. The tendency was noticed that mouflon mortality was less related to the number of days with snow cover than roe deer and red deer. Obtained data showed rather weather effect of snow cover on red deer and roe deer in the environment of the Owl Mountains. When supplementing winter fodder, the local species were not strongly flocking to supplemented fodder as did the mouflon, which does not travel long distance but stays in proximity to feeding places in large groups and uses common trails in the snow. However even sporadic heavy frosty days had an impact on mouflon mortality.

Temperatures below $0^{\circ} \mathrm{C}$ had a significant impact on total mortality of the three species of ungulates $(r=0.69 ; \mathrm{P} \leq 0.05)$ as well as severity of climate during winter ( $\mathrm{n}$ days with temp. below $-10^{\circ} \mathrm{C}: \mathrm{r}=0.77$; $\mathrm{P} \leq 0.05$ ). Low temperatures (below $-10^{\circ} \mathrm{C}$ ) occurs in this area only 1 day/year (season) on average and it is difficult to clearly demonstrate its influence on ungulates mortality, except the mouflon. Low tolerance of low temperatures was observed in mouflon - single days with temperature below $-10^{\circ} \mathrm{C}$ significantly increased mortality in the mouflon population in the Owl Mountains $(r=0.75, \mathrm{P} \leq 0.05)$.

Our own results showed that red deer mortality in the Owl Mountains was related to the depth of snow cover - Figure 2. Regression equation showed that the deeper the snow cover was (range 10-60 cm), the higher the mortality recorded. The same trends were also observed in the roe deer and mouflon, but correlations had not reached significance level.

Years when high mortality of roe deer was recorded coincided with low mortality of red deer and mouflon. This may be related to differences between behavioural and morphological adaptations of analysed species to local environment. Effect of low temperature on roe deer was not so different to other species tested, but roe deer showed to be the most tolerant to snow cover. Therefore, performed cluster analysis showed that roe deer's tolerance to weather conditions was the most different - Figure 3.

Results of cluster analysis comparing mortality rate in red deer, roe deer and mouflon due to combined climatic conditions showed that the pattern of mortality diverge between roe deer and other two species (Figure 3, see Table 1). 


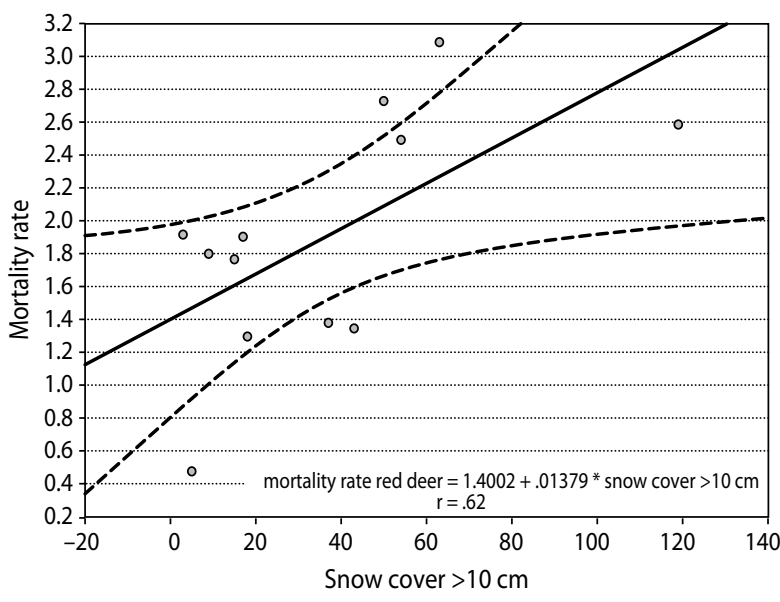

Figure 2. Relation between the depth of snow cover $>10 \mathrm{~cm}$ and red deer mortality in the Owl Mountains

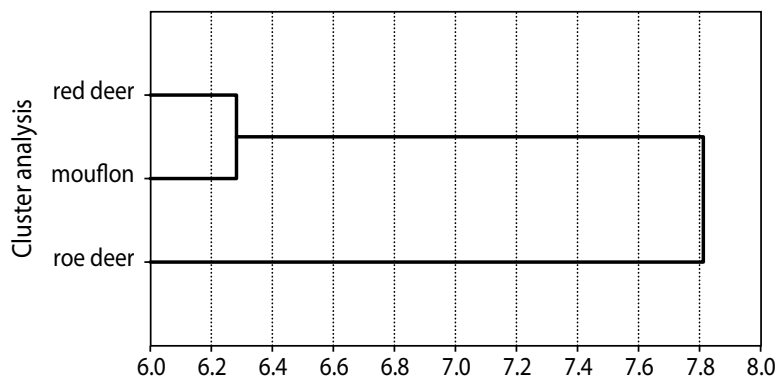

Figure 3. Results of cluster analysis (method agglomerative) comparing mortality rate in red deer, roe deer and mouflon due to climatic conditions. Axis X, present distance

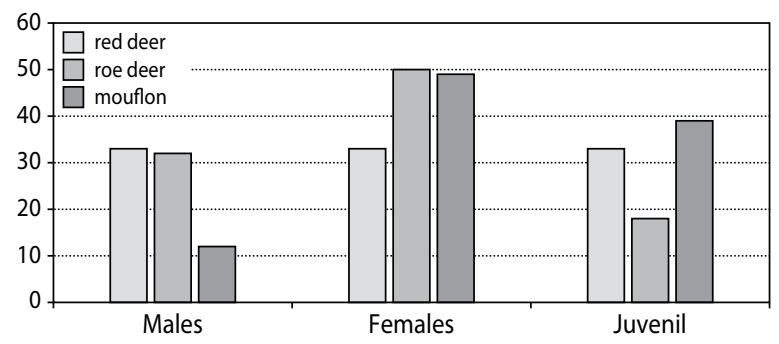

Figure 4. Mortality by sex and age class (juveniles vs. adults) in the three species of ungulates in the Owl Mountains - percentage share

Analysis of mortality by sex class showed much lower mortality recorded for adult males of roe deer and mouflon than females - Figure 4. The lowest mortality was noted for mouflon males and juvenile roe deer. The highest mortality was observed for females of roe deer and mouflon. The losses in juvenile groups of red deer and mouflon were 30 and $40 \%$, respectively, of total recorded mortality, while roe deer juveniles' mortality was two times lower than the mouflon.

\section{Discussion}

Winter mortality prevails in wild ungulates as stated by Kałuziński (1982), Hadjisterkotis (2002), and summer mortality is minimal and usually due to sporadic accidents. Fruziński and Łabucki (1982) stated that only up to $20 \%$ of lost animals were documented in the strictly controlled forest habitat. Modelling relations between weather data and mortality of free-living animals in defined biotopes might be a valuable tool in game management. Clutton-Brock and Albon (1982) based on meteorological data predicted with $95 \%$ accuracy the level of mortality in red deer. However, no such studies have been performed in the Owl Mountains yet. In Poland, a similar theme was taken up by Okarma et al (1995). These authors showed that mild winters in Białowieża National Park (BNP) had no effect on the mortality of ungulates, while snow cover $>40 \mathrm{~cm}$ (up to $1.0 \mathrm{~m}$ ) had a detrimental effect - caused massive mortality in deer populations. For the most years analysed in BNP, snow cover did not exceed $10 \mathrm{~cm}$, while low temperatures below $-10^{\circ} \mathrm{C}$ (up to $-25^{\circ} \mathrm{C}$ ) were recorded each year. These are different climate conditions than in the Owl Mountains studied, where winter temperatures were more moderate (average number of days with temperature below $0^{\circ} \mathrm{C}=33$ with sporadic days with temperatures below $-10^{\circ} \mathrm{C}$ ); however, snow cover is higher (average maximum cover over the years $=46 \mathrm{~cm}$, the highest $=106 \mathrm{~cm}$ ) and snow cover over $10 \mathrm{~cm}$ last on average 38 days per year. An analysis of the mortality of ungulates in this study area showed clear relation with snow and frosty days. Similar results were documented by Okarma et al. (1995) between mortality in roe deer and red deer and snow cover in BNP in more severe winters $(r>0.8)$. Average snow cover in BNP made wild ungulate more susceptible to wolf attacks. The main culling reason in red deer and roe deer in BNP is wolf and lynx predation during winter, while this is not a case in the Owl Mountains. Kossak (2003) documented yearly mortality of red deer in forest complex Puszcza Białowieska (Poland) at the level of ca. 5\% of the total population, while estimated red deer mortality in Bieszczady Mountains was ca. 11\% (Perzanowski 
and Krzakiewicz 2000). These data are higher than that obtained in this study $(1.86 \%)$, because of lack of predators common to the Białowieża Forest and Bieszczady.

Observations made by Kałuziński (1982), who studied the population dynamics of roe deer in experimental lowland area near Poznań (Poland), showed that winter mortality reached $57 \%$ of annual mortality and the highest winter mortality in roe deer was in juvenile groups. Dramatic high level mortality in roe deer was documented during the period of 10 days with low temperature $\left(-13^{\circ} \mathrm{C}\right)$ and snow cover height ca. $15 \mathrm{~cm}$ (Kałuziński 1982). Hadjisterkotis (2002) documented the highest mortality among mouflon in winter, where the most important factors were road kills, poaching and falling from cliffs.

The natural biological process is adaptation of species to conditions of climate. Telfer and Kelsall (1984) gave good example of anatomical and ethological fitness of Ovis canadensis (Shaw, 1804) and wapiti (Cervus canadensis, Erxleben, 1777) to snow cover. Based on chest height above the ground and pressure for snow and ethological findings, morphology and behavioural indices were constructed to compare the ability of different species to cope with winter conditions. Authors of this study described adaptation traits of several wild ungulates and showed that wild sheep (bighorn sheep and dall sheep) were less adapted to winter conditions when compared with deer (white-tailed deer). Similar, anatomical studies (Takatsuki 1992) showed that sika deer (Cervus Nippon, Temminck, 1838) preferred snow cover below $50 \mathrm{~cm}$ and cover above $100 \mathrm{~cm}$ was out of its acceptance. Despite numerous adaptations, studies of physiology of ungulates demonstrated that energy expenditure incurred by the animal floundering in the snow grows linearly with the increase in the depth of snow and its density (Parker et al. 1984).

In the present study, it was demonstrated that mortality rate of red deer, roe deer and mouflon are related to moderate snow cover and mild winter temperatures occurring in Central Europe. The most adapted to winter climate used to be the roe deer, despite the higher documented total mortality than red deer and mouflon (Table 1). During the food shortage, the roe deer is able to find alternative sources of food (Mysterud and Østbye 2006). Kamler et al. (2011) showed in the winter diet of roe deer that coniferous needles may replace the unavailable grass at this time. Roe deer for a long time can use snow as a water source, which contributes to its high resistance to high snow cover (Hooland et al. 1998). As indicated in the study of Mátrai and Kabai (1989), the degree of food niche overlap between roe deer and red deer may be only $28 \%$. Roe deer during the winter eats much less grass than red deer, and much more forbs and fruits - the plant matter available above the snow, up to $80 \mathrm{~cm}$ (Gębczyńska 1980). However, Mysterud et al. (1997), Mysterud and Østbye (2006) and Helle (1980) showed that roe deer preferred areas with low snow cover and moved to lower land with trees, and the depth of snow was the primary factor of biotope choice by this species. The red deer's diet is dominated by low-growing plant species. According to studies by Gębczyńska (1980), the red deer's winter diet may be even as low as moss growing plants and roots. In this study, from the three species analysed, mouflon is a newcomer from Southern Europe - introduced here ca. 100 years ago. Compared with the local wild ungulates, it had the lowest adaptation to frosty winters. As stated by Wehausen (1992), low temperatures may affect the diet quality of mountain sheep. Interestingly, mouflon mortality is similar to that of native species - red deer and roe deer (Figure 3). It seems that the influence of snow cover is important for mouflon locomotion, but mouflon remain near places where animals are supplementally intensively fed (Urbańska et. al 2012). Its high mortality in the winter is therefore mainly due to low temperatures. In the native habitat of mouflon, the average yearly temperature is ca. $12^{\circ} \mathrm{C}$ (Sampolo, Corsica $=11.8^{\circ} \mathrm{C}$ degrees - Rome and Giorgetti 2007), while in the Sudety Mountains, yearly temperature is ca. $8^{\circ} \mathrm{C}$.

The results obtained in this work are similar to ones obtained for other wild sheep. Analysis of reproduction success in dall sheep (Burles et al. 1984) indicated stronger influence of temperature $(r=-0.66)$ than snow cover $(r=-0.45)$ - while winter severity index (including both weather factors) was the most related ( $\mathrm{r}$ $=-0.79)$. Our results showed positive relation $(\mathrm{r}=0.75)$ between very low temperature and mouflon mortality in conditions of the study area, while red deer and roe deer were less affected. Comparing species of deer in relation to the mouflon, we must remember the different biology of these animals. Telfer and Kelsall (1984) demonstrated variability of the ungulate species in coping with snow cover. Wild sheep better utilized fodder covered by snow, while white-tailed deer preferred ingesting fodder above the snow - as a result, fodder in- 
gested by sheep contained more moisture than freeze dried fodder eaten by deer.

An analysis of the mortality by sex and age class in the three species of ungulates in the Owl Mountains showed the highest mortality in females (roe deer, mouflon). Kamler et al. (2007) showed in BNP that red deer mortality was connected mainly with juvenile class animals because of the presence of natural predators. In our research performed in the Owl Mountains, where there is a lack of wild predators, mortality in juvenile groups was moderate (about 30\%). Hadjisterkotis (2002) showed that most often deaths in mouflon were related to males; however, that was opposite to this study (Figure 4), where higher losses were in females (ca. 70\%).

\section{Conclusion}

Low ambient temperature is a factor that unquestionably affects all three ungulate species in the Owl Mountains. Roe deer species seems to be environmentally plastic and are doing quite well in severe winters. Mouflon is a species least resistant to frost, which may indicate a lack of appropriate adaptation to Central European climate.

Tolerance of red deer to the snow cover is much lower at low temperatures due to the fact that this species, during the period of snow cover, has limited access to the plants covered with snow and difficult access to food base, which results in worsening of their health status. The phenomenon of the lack of proper food practically does not apply to the mouflon because of supplemented feeding during the winter.

\section{Acknowledgements}

We would like to thank the Ląbęcki Lucjan and Adam Dziubacki Forests Administration in Wrocław for help with data collection.

\section{References}

Albon S.D., Clutton-Brock T.H. Guinness F.E. 1987. Early development and population dynamics in red deer. II. Density-Independent effects and cohort variation. Journal of Animal Ecology, 56, 69-81.
Barichello N., Carey J. 1988. Snow depth as a likely factor contributing to the decline of a sheep population in the central Yukon. Biennial Symposia. Northern Wild Sheep and Goat Council, 6, 282.

Burles D., Hoefs M., Barichello N. 1984. The influence of winter severity on dall sheep productivity in southwestern Yukon. - a preliminary assessment. Biennial Symposia. Northern Wild Sheep and Goat Council, 6, 282.

Clutton-Brock T.H., Albon S.D. 1982. Winter Mortality in red deer (Cervus elaphus). Journal of Zoology, 198, 515-519.

Clutton-Brock T.H., Major M., Albon S.D., Guinness F.E. 1987. Early development and population dynamics in red deer. I. Density-dependent effects on juvenile survival. Journal of Animal Ecology, 56, 53-67.

D'Eon R.G. 2004. Snow depth as a function of canopy cover and other site attributes in a forested ungulate winter range in southeast British Columbia. $B C$ Journal of Ecosystems and Management, 3 (2), 1-9.

Fruziński B., Łabudzki L. 1982. Demographic Process in a Forest Roe Deer Population. Acta Theriologica, 27, 365-375.

Furmankiewicz M. 2006. Środowisko geograficzne. In: W cieniu Wielkiej Sowy. Monografia Gór Sowich (ed.: T. Przerwa). Srebrnogórska Oficyna Wydawnicza, Dzierżoniów, 21-31.

Gębczyńska Z. 1980. Food of the Roe Deer and Red Deer in the Białowieża Primeval Forest. Acta Theriologica, 25 (40), 487-500.

Goodson N.J., Stevens D.R., Baily J.A. 1991. Effect of snow on foraging ecology and nutrition of bighorn sheep. Journal of Wildlife Management, 55 (2), 214-222.

Goodson N.J. 1992. Management implications of an intensive study of winter foraging ecology of bighorn sheep. Biennal Symposia. Northern Wild Sheep and Goat Council, 8, 58-67.

Hadjisterkotis E. 2002. Seasonal and monthly distribution of deaths of Cyprus mouflon Ovis gmelini ophion. Pirineos, 157, 81-88.

Hebblewhite M., Pletscher D.H., Paquet P.C. 2002. Elk population dynamics in areas with and without predation by recolonizing wolves in Banff National Park, Alberta. Canadian Journal of Zoology, 80, 789-799. 
Helle P. 1980. Food Composition and Feeding Habits of the Roe Deer in Winter in Central Finland. Acta Theriologica, 25 (22), 395-402.

Jędrzejewski W., Jędrzejewska B., Okarma H., Ruprecht A. 1992. Wolf predation and snow cover as mortality factors in the ungulate community of the Białowieża National Park, Poland. Oecologia, 90, 27-36.

Kamler J.F., Jędrzejewski W., Jędrzejewska B. 2007. Survival and cause-specific mortality of red deer Cervus elaphus in Białowieża National Park, Poland. Wildlife Biology, 13 (1), 48-52.

Kamler J.F., Homolka M., Heroldovả M., Literảkovả P. 2011. Feeding strategy of wild herbivores in habitat of limited food resources. Wildlife Biology in Practice, 7 (1), 46-55.

Kałuziński J. 1982. Dynamics and Structure of a Field Roe Deer Population. Acta Theriologica, 27, 385-408.

Kittle A.M., Fryxell J.M., Desy E.G., Hamr J. 2008. The scale-dependent impact of wolf predation risk on resource selection by three sympatric ungulates. Oecologia, 157, 163-175.

Kondracki J.A. 2011. Polish Regional Geography. PWN, Warszawa. (In Polish)

Kossak S. 2003. Size and structure of red deer (Cerphus elaphus L.) population in promotional forest complex "Puszcza Białowieska" in 1997-2001. Forest Research Papers, 4 (964), 65-89. (In Polish)

Kumpula J., Colpeart A. 2003. Effects of weather and snow conditions on reproduction and survival of semi-domesticated reindeer (R. t. Tarandus). Polar Research, 22 (2), 225-233.

Loison A., Langvatn R., Solberg E.J. 1999. Body mass and winter mortality in red deer calves: disentangling sex and climate effects. Ecography, 22, 20-30.

Matrai K., Kabai P. 1989. Winter Plant Selection by Red and Roe Deer in a Forest Habitat in Hungary. Acta Theriologica, 34 (15), 227-234.

Mech L.D., McRoberts R.E., Peterson R.O., Pare R.E. 1987. Relationship of deer and moose population to previous winter`s snow. Journal of Animal Ecology, $56,615-627$.

Messier F. 1995. Is there evidence for a cumulative effect of snow on moose and deer populations? Journal of Animal Ecology, 64, 136-140.
Mysterud A., Østbye E. 2006. Effect of climate and density on individual and population growth of roe deer Capreolus capreolus at northern latitudes: the Lier valley, Norway. Wildlife Biology, 12 (3), 321-329.

Okarma H., Jędrzejewska B., Jędrzejewski W., Krasiński Z.A., Miłkowski L. 1995. The roles of predation, snow cover, acorn crop, and man-related factor of ungulate mortality in Białowieża Primeval Forest, Poland. Acta Theriologica, 40 (2), 197-217.

Parker K.L., Robbins C.T., Hanley T.A. 1984. Energy expenditures for locomotion by mule deer and elk. L. Journal of Wildlife Management, 48 (2), 474-488.

Perzanowski K., Pradel A., Sikorski M.D., Mydlarz J. 1982. Food Resources for Deer in Niepołomicka Forest. Acta Theriologica, 27, 509-519.

Perzanowski K., Krzakiewicz H. 2000. Red deer population in the Bieszczady Mountains. Monographs of Bieszczady, 9, 157-178. (In Polish).

Picton H.D. 1984. Climate and the prediction of reproduction of three ungulate species. Journal of Applied Ecology, 21, 869-879.

Portier C., Festa-Bianchet M., Gaillard J.M., Jorgenson J.T., Yoccoz N.G. 1998. Effect of density and weather on survival of bighorn sheep lambs (Ovis canadensis). Journal of Zoology, 245, 271-278.

Rome S., Giorgetti J.P. 2007. Corsican mountains and its climatic feature. Meteorology, 59, 39-50. (In French).

Takatsuki S. 1992. Foot morphology and distribution of sika deer in relation to snow depth in Japan. Ecological Research, 7, 19-23.

Telfer E.S., Kelsall J.P. 1984. Adaptation of some large north American mammals for survival in snow. Ecology, 65 (6), 1828-1834.

Urbańska M., Kraśkiewicz A., Grześkowiak A., Tracz M., Gierszał H. 2012. Use of European bison's artificial feeding site by fallow deers and mouflons in the Western Pomerania. Proceedings of the Center for Nature and Forestry Education, 33 (4), 319-326. (In Polish).

Wehausen J.D. 1992. The role of precipitation and temperature in the winter range diet quality of mountain sheep of the Mount Baxter Herd. Sierra Nevada. Biennial Symposia. Northern Wild Sheep and Goat Council, 8, 279-292. 